\title{
The Application of Traditional Folk Art in Modern Environmental Art Design
}

\author{
Cao Shang Qiu
}

Jingdezhen ceramic University

333403

Keywords: traditional folk art; modern environmental art design; application

\begin{abstract}
Traditional folk art is development from the long-term social practice of our people. China's 56 ethnic groups have different national culture. Long-term historic culture has accumulate to formed some excellent cultural works. However, with the Long history of the development process, some folk art gradually fade out of people's vision. This article will use traditional folk art in modern art design, and explore the application of folk art is related to design of environmental art.
\end{abstract}

\section{Introduction}

In the long history of the traditional folk art has experienced a long period of development and historical accumulation, the formation of our country's brilliant folk art works, folk art works will be national culture, religious beliefs, living customs and personal aesthetic awareness have continuous innovation and development, after thousands of years of historical heritage, can be retained to today. Traditional folk art has profound cultural heritage and national characteristics, use traditional folk art in modern environmental art design, can make the modern environment art design more perfect, can make the environmental art design level increased significantly.

\section{The Traditional Folk Art Related to the Overview}

Louis Kang said that the future is evolved from the melting past, folk art and modern environmental art design aspects of mutual contact and promote each other. Traditional folk art is occupies an important position in the traditional culture of our country,in today's highly regard spiritual and cultural stage, pay attention to the traditional folk art is develop an unprecedented realm, the traditional folk art is the crystallization of the wisdom of our working people, it is China's outstanding national culture, it plays an irreplaceable role [1]. Folk art belongs to a class of plastic arts, its presents a variety of artistic style,it is the embodiment of the essence of national culture, environmental art designers can refine some essence of the elements, into the modern art environment design, So that the modern environmental art design have more connotation, to create more rich cultural heritage and national characteristics of space art.

\section{The Specific Application of Folk Art in Modern Art Design}

The creative ideas of folk art can be applied in the current environmental art design, such as prayer, evil spirits and so on. These creative ideas can be used in the process of modern environmental art design, and some of them are extended. Art charts can also be used in modern graphic design. Whether it is graphics or meaning, the modern environmental art design can be extracted essence from the traditional folk art design .

The Application of Folk Art Concept. Folk art map contains a large number of characters, animals and cover different types of abstract description, a considerable part of the pattern use homophonic and other different ways give a better image to the variety of things, folk art works with rich imagination, through the abstract, Exaggerated and different decorative techniques to achieve a sense of beauty of the effective performance. Folk art works, there are a variety of classic symbols, for example, "The carp has leaped through the dragon's gate" performance is achieve success and 
win recognition, "rich and rich" is the family wealthy, many folk art works represent a different Meaning, the modern environment art design process to make full use of folk art design concept, can enhance the design of a cultural heritage.

The Use of Modeling. Folk art modeling elements originated in people's daily life practice, people continue to practice and sum up experience in the process, from the actual life of some of the useful elements of continuous innovation, resulting in the later some of the fine folk Art style, for the human life and spirit to provide services. From the perspective of folk art, modeling is an important form of expression, giving a sense of visual beauty, such as clay sculpture, New Year paintings and noodles are people in the long-term practice of continuous innovation on a profound Connotation to interpretation ,New Year paintings exorcise evil spirits, but also to meet people's visual aesthetic, used to watch, such as dough modeling through to shape the different characters or animals, to meet people's spiritual needs [2]. Folk art in the design is reflected in two aspects, the one is relatively exaggerated modeling, attaches great importance to its decorative, but also to meet the broad masses of the people's heart, exaggerated means to show is a simple, without any modification, But more real; the second is the creation of folk art is derived from the broad masses of people continue to produce activities, the creation of a simple expression of emotion, and did not use specific things as a creative basis, but to play their own imagination and creativity, it will be a kind of people's expetation and good wish into the works of art, reflect the people's good vision of the future. Modern environment design make full use of folk art design inspiration for the design work to bring great help for folk art related to some of the auspicious patterns are currently applied to the design of the building, and produced a great aesthetic effect, modern design for the folk The drawing of art should be based on the pattern of folk art, carry out a profound study of its pattern, to understand some of the elements it uses, and to have some reference for his design work, to ensure that his work has a certain character of time, and with the traditional folk art fusion.

The Use of Color. Folk art works are from the people. The humanity basic of art is relatively deep, in terms of color is close to nature, the performance is a simple and elegant qualities, color design for environmental design has an important impact,use of color too much, it will be very tacky,but too little, there will be no effect. Modern design process, the color can be fully reference to the application of folk art color, you can achieve the perfect combination of modern design and folk design, folk different colors represent different meanings, in the five elements, white represents gold,cyan represents wood, Black represents the water, red on behalf of the fire, yellow on behalf of the soil, followed by the corresponding North,East,Centre,South,and West, have a different meaning. In the process of modern environmental design to fully integrate into these implications, it can give people a different visual effects, can make the modern design more moral.

The Use of Regional Elements. China's vast territory, rich national culture, has a wealth of folk art art, due to geographical differences, folk art with obvious geographical differences, but also has a different regional style, the traditional folk art is also very complete, for example, Tianjin Clay figurines, Weifang plank paintings have a strong regional characteristics [3]. Modern environmental design should be full of this regional characteristics into the design concept, the appropriate integration and innovation, design a rich regional characteristics of the design products. This regional characteristics after years of development and accumulation form a unique geographical features in different ethnic and different environments ,the local people have become accustomed to the region where the culture and customs, has reached a kind of cultural consensus, in the modern environment design can not be hard to apply it to other areas, it is possible to put the cart before the horse, this approach will only cause a culture of a disagreement, lost its characteristics. The application of the regional elements of folk art must consider the regional differences, to be effective with the actual life of the combination, to understand the local customs, national characteristics, only in this way to make folk art geographical elements better integrated into the modern design .

Folk art is the crystallization of the wisdom of the people and the symbol of national culture, but it is not intact to be followed by people ,we should understand the culture of its expression of a connotation, to process and refine it, The essence of the part, to understand it's reflection of a social 
background. Modern environmental art designer can not blindly copy some of the folk art design content, but to be based on the refining, combined with the current trend of social development, continuous innovation, give full play to the design of folk art ideas, which it requires modern designers to have rich cultural knowledge and advanced design concepts, master the application of modern information technology, and blend in some modern elements, the traditional folk art to continue to innovate, so that their design concept more accord with the current society development need.

\section{Conclusion}

To sum up, with the continuous development of social economy, people's spiritual need continue to improve, the design of environmental art more and more challenges, people's demand for the environment gradually improved. Designers should fully understand the traditional folk art design, absorb it's essence, and combined with modern design concept, fully understand the cultural characteristics of various nationalities, absorb some of the essence of the part, fuse the integration of folk art and modern elements, can reflect the unique charm of modern environmental art design.

\section{References:}

[1] Pi Jia. Traditional folk art in the use of modern environmental art design [J]. Landscape applications, 2015 (4)

[2] Zhang Jun. Traditional folk art in the use of modern environmental art design [J]. Academic preface, 2015 (23)

[3] Du Yishu. Folk art in modern environmental art design application [J]. Art Education Research, 2016, (22) 